\author{
N. Ichanska, A. Gritsenko, V. Shefer \\ Poltava National Technical Yuri Kondratyuk University, Poltava, Ukraine
}

\title{
DEVELOPMENT OF SOFTWARE SERVICE FOR SALE OF VEHICLES
}

\begin{abstract}
In article the software on car sale is studied, its development and testing, is constructed model of creation and development of the website in car sale on the example of the website on sale of cars of the Japanese vendors. The work is that it is the active Internet users who come to the aid of online stores, or, for example, sites selling car services designed to view the relevant equipment and characteristics of cars, without leaving their own home. Unlike a regular store, the Internet resource is open 24 hours a day, 7 days a week, available to any user, anywhere in the world and does not require financial costs for renting a room, greatly reduces the cost of staff. The popularity of Internet services is increasing day by day. It is no secret to anyone that a well-"untwisted" Internet resource brings revenue not less than its usual counterpart, and keeping and making the Internet resource in order is more profitable - there is no cost of renting a road and other expenses An object of research of work are implementers of Web resources. The main objectives are implementation of development tools of structure of the Website and the interface, the choice of means for their implementation, program implementation of the website. The work purpose - improvement of quality of information visualization from automobile subject of the software by creation of the modern website. Results - it is offered the strategy of development for the website and its further development that allows to provide the competing possibilities of the created website. The technique of creation of the software is described and it is accented on parameters of convenient use of the website by the user, the main problems and shortcomings of the existing websites and their implementation in comparison with are covered again. Conclusion - the work proposed principles of program services offered allow to provide the competing possibilities of online store, in comparison with analogs. Methods are considered realize the main objectives of design of information filling of the website.
\end{abstract}

Keywords: software, development of service, testing of service, "usability", software, online store, content management system, HTML5, CSS3, structure of the website.

\section{Introduction}

Modern objective reality is establishment to different spheres of life activity of the personality, society and the state of the latest information technologies, creations on their basis of varying complexity of the information systems intended for bystry information exchange and access to different information sources [1].

Having carried out infographics of modern development of technologies and systems as one of criteria of the level of development of the state and the tool of an intensification of all processes in society, Ukraine, along with other countries, is interested in development of information infrastructure, by use in all spheres of business activities of the opportunities given by wide area networks of data transmission. A wide area network extremely perspective communication medium and communications on the example of which every year we can observe its development.

Thanking overflows of communication communications in a wide area network of people had an opportunity to communicate within all planet, irrespective of borders and distances. The Internet is one of signs of transition of society to information stage of development. 40 years - the Internet developed from confidential military technology into public, open system which influenced development of the planet and mankind in general.

For the last decades thanks to development of the Internet it was selected the direction - Web programming. With updating of standards of the requirement to the websites strongly changed, and now on the Internet it is necessary to provide for successful representation to the organization to the clients contact forms, product catalogs, subscriptions, mailings with the laconic and thought-over design.

Adaptivity of the website is provided by means of modern HTML and CSS technologies. Web programming on client side includes a set of programming aids and a marking of the text. These means are divided into two main types: server and client $[2,3]$.

For today the websites business cards of the separate organizations purchase popularity. "Online" business cards is usually given in such detailed information on the owner of the website, and the small list of the main characteristics of cars, the corresponding sets and the price of them is shown.

The main task of such websites is providing detailed information about about the choice of sets as budget and expensive variations. Before creating the website on car sale, it is necessary to like autosubject, that is will be on sale and will interest it buyers, to satisfy all their requirements. Because many will not give the money to our not simple time for low-quality By the way, in this case cars, with a small resource of use, for example new domestic cars. In this case, the website will offer new cars, and cars with a run, but at the same time with the Japanese quality $[3,4]$.

The number of people who prefer to find previously all necessary information in the Internet grows, however there is not a lot of resources with autosubject. In the presence of own website, visitors whom purchase of a car or diagnostics of faults of the car interests will make a basis of target audience that will allow to receive much more visitors on the website.

Therefore, development and deployment of the Website on car sale is urgent and reasonable [2, 3]. 


\section{Evaluation of a problem and problem definition}

Development of the websites of automobile subject includes a complex of actions which purpose consists in attraction on a resource as it is possible the bigger number of visitors, that is, prospective clients. It is known that from 80 to $90 \%$ of users are visited the website by means of such search giants as "Bing" and Google therefore also the profit of owners of a resource depends on bots as a result. One of the main distinctive features of the websites of an avtotematika is that purchase and car sale or spare parts practically always happens the mode.

Therefore the main objective of such website - to induce the potential buyer to visit an outlet and to purchase the car or necessary spare parts [3]. Features of search development of the website of automobile subject consist in specific contents of information which fills a resource. By drawing up a request of search for the automobile website it is necessary to pay attention to keywords which not only contain the root "car", but also it is a lot of other words which characterize automobile subject, for example, of "bus", "technical characteristics", "tuning", "spare parts", "repair of the check point and automatic transmission", "aerographics" and many others. Besides, it is worth paying attention and to the formulation of a request. For example, issue on demand "car" will be much bigger, than on demand "to purchase the car" or "to purchase the Toyota car".

Respectively, the request is shorter and simpler, the it is more difficult to untwist on it the website as the competition very big. For descriptive reasons it is possible to tell that on a request "car" of Google issues about 300000000 results, and on a request "to purchase the Toyota car" - about 800000 . The optimizer's task to define what requests will be the most effective in a specific case, and to be on their basis the semantic center the website. The Internet contains a significant amount of the Websites on car sale in the present, however all of them are intended for what search of declarations in car sale, is not convenient for the normal user. An example of such website it is represented in the fig. 1. User-friendlier website on car sale was designed that is represented in the fig. 2.

The work purpose - improvement of quality of reproduction of information from automobile subject by creation of an Internet resource.

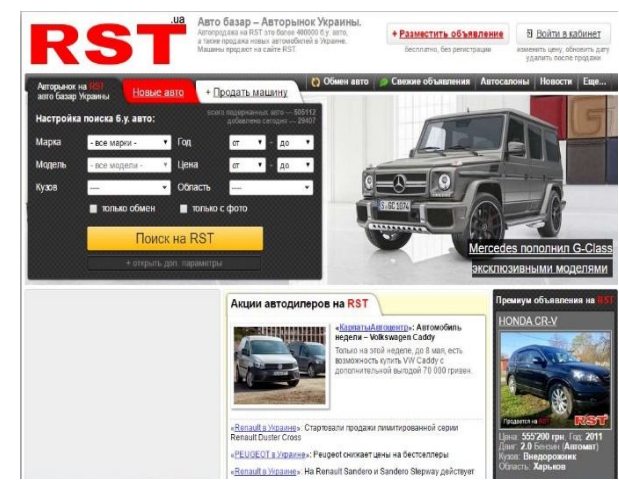

Fig. 1. Typical website on car sale

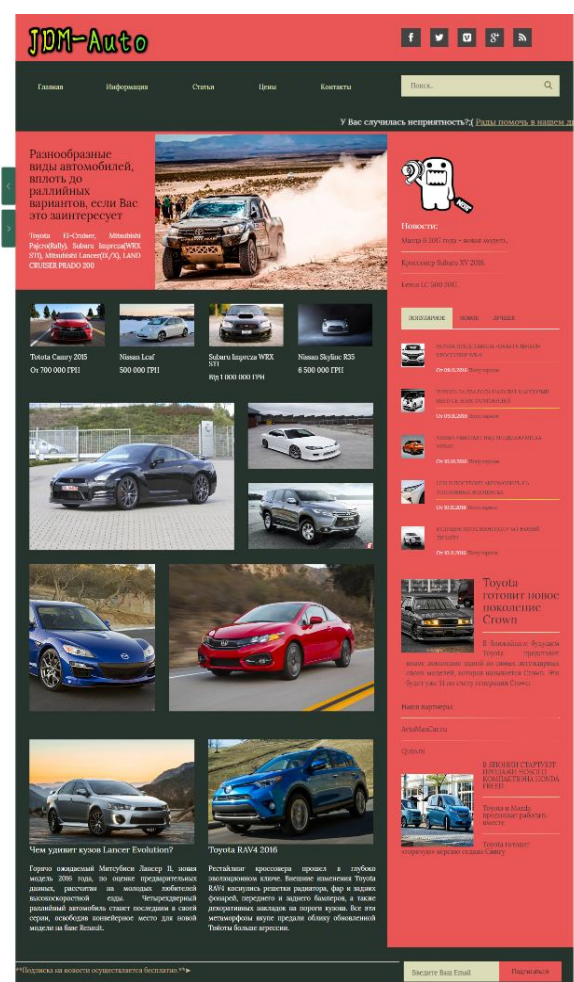

Fig. 2. Own designed website on car sale

\section{Statement of the main material}

Creation of the website - extremely laborious process, especially when a resource is created by one person. Earlier process of creation of the websites was available only to the large companies. Today creation of the websites in Ukraine and beyond its limits is a popular service which is available to everyone to the person. Demand for service in development of the websites grows in using areas, the automobile world to that not an exception.

Today, bigger demand gather the information websites of the organizations or subdivisions. So, we will define problems which are solved by the website on car sale. This work is that active Internet users are come to the rescue by Online stores, or for example the websites on car sale intended for viewing of the corresponding sets and characteristics of cars without coming out own house. Unlike normal shop, the online store is open 24 hours a day, 7 days a week, is available to any user, in an every spot on the globe and does not demand finance costs on tenancy, considerably cuts staff expenses.

Popularity of Online stores grows every day. Already for anybody not a secret that well the Online store brings "promotions" the income not less, than its normal analog and to hold and make Online store much profitably-there are no costs for the road lease and other expenses

Usability is a property of a product to be suitable for use. Also defines the general degree of convenience of a subject when using. If to tell about the website as about defined an Internet product, then it also possesses the usability in a varying degree. The usability is a characteristic which first of all is turned to visitors of the website. Search engines do not evaluate it, it only 
indirectly influences ranging. The usability is more qualitative, the website is more popular, the product, the more traffic, and respectively is on sale better, issue in search engines is higher - everything is interconnected.

The low level of a usability, respectively, reduces attendance of the website. However, it does not mean at all that this website does not contain good content. On the contrary, content can be interesting, useful, and a usability - low. For example, interesting information is on the page of the multi-level menu with muffled the name which to reach neither one, nor in two clicks it will not turn out in any way. Or information is typed, but located so that it is impossible to read it [3].

The usability is considered high if having for the first time got on the website, the client at once understands how to use it. One more sign: the client, having got on the website suddenly, without problems remembers and easily is guided. The third sign is more from discharge of psychology, but is also important: it has to be pleasant to user to use the website. As criterion of a good usability it is possible to consider also lack of errors when using of the website. It is especially important, so far as concerns big the unrolled portals to requirements of registration, filling of questionnaires, interactive polls, games. In this respect the websites with games are especially indicative: the client, having visited the website and not having understood how to play what to begin with, having made several attempts, yet not the website $[5,6]$.

Important, it is possible to tell - the basic, software development of the website will be a development stage of the website. For a start, we will select a convenient development environment. Also we will carry out the alternative analysis of software of implementation and database management systems. Having selected the most suitable option for implementation of the tasks, we realize the main modules of the website.

Many Web designers agree in opinion that one of the main problems of Web design - variety of browsers and platforms, each of which differently supports HTML and the script.

With release of each new browser their characteristics and opportunities improve, but it does not mean that earlier versions at the same time disappear. In the majority people are not inclined to pursue for the latest and the best. One are content with what they have, and others, most likely, work at computers of firms or organizations which selected browsers for them $[3,4]$. How to make design of the Web page esthetic and technically interesting, without ignoring at the same time owners of the previous versions of browsers? Really

In Web design the main objective - to make content of the page available to most of users.

The successful design decision lies in "menu" of needs of audience and in clear vision as the website will be used [6]. Most of programmers in the work are guided by GoogleChrome and Firefox as they occupy the main market share. Nevertheless, there is some other browsers which can be taken into account, however almost all of them will be based on projects (Chromium, some also with compression of data volume of the Operaturbo project) Creation of the website - quite not easy process if it is created only by one person. Earlier development of the websites was available only to the large organizations. But today creation of the websites is a widespread type of a earnings and is available to everyone.

\section{Conclusion}

The principles of implementation of the website were analyzed. Also the basic principles which will be applied at design of information filling of the website and navigation aids were defined. It was defined types of information support and are briefly characterized them.

Placement of the latest news from the automobile world, the interesting facts and events, the discussed problems, new cars is reasonable.

The module of news is in detail described and realized, provides adding, editing and removal of news, also it provides output of the latest news on the homepage of the website. Also it was developed the interface and logic of work of the website, completely realize functions, are assigned to them. For more informative filling it was used freeze frame images which provide content of the website of a variety. Also it was shown the ropes and are considered such concept as "usability".

\section{REFERENCES}

1. B. Khoghan HTML5 y CSS3. Veb-razrabotka po standartam novogho pokolenyja- 4-e yzd. - SPb.: Yzdateljskyjdom «Pyter», 2010. - $260 \mathrm{~s}$.

2. PiterLabbers, BrajanOlbers, Frenk Salim HTML5 dlya professionalov. Moshnyeinstrumenty dlya razrabotkisovremennyh veb- prilozhenij - SPb.: Izdatelskijdom «Piter», 2011. - $272 \mathrm{~s}$.

3. Usability, available at: https://en.wikipedia.org/wiki/Usability

4. Romanyuk O.N. Veb-dizajn i komp'yuterna grafika. Navchalnij posibnik / O.N. Romanyuk, D.I. Katyelnikov, O.P. Kosovec. - V.: VNTU, 2007. - $147 \mathrm{~s}$.

5. E. Frimen, E. Frimen. Izuchaem HTML, XHTML i CSS $=$ HeadFirst HTML with CSS \& XHTML. — P.: «Piter», 2010. — $656 \mathrm{~s}$.

6. Stiven Shafer.HTML, XHTML i CSS. Bibliya polzovatelya, 5-e izdanie.—M.:«Dialektika», 2010.—656 s.

\section{СПИСОК ЛІТЕРАТУРИ}

1. Б. Хоган HTML5 и CSS3. Веб-разработка по стандартам нового поколения- 4-е изд. - СПб.: Издательскийдом «Питер», 2010. - 260 с. 
2. ПитерЛабберс, БрайанОлберс, Фрэнк Салим HTML5 для профессионалов. Мощныеинструменты для разработкисовременных веб- приложений - СПб.: Издательскийдом «Питер», 2011. - 272 с.

3. Юзабіліті [електронний ресурс] Режим доступу: http://ru.wikipedia.org/wiki/Юзабіліті!.

4. Романюк О.Н. Веб-дизайн і комп’ютерна графіка. Навчальний посібник / О.Н. Романюк, Д.І. Катєльніков, О.П. Косовець. - В.: ВНТУ, 2007. - 147 с.

5. Э. Фримен, Э. Фримен. Изучаем HTML, XHTML и CSS = HeadFirst HTML with CSS \& XHTML. - П.: «Питер», 2010. $-656 \mathrm{c}$

6. Стивен Шафер. HTML, XHTML и CSS. Библия пользователя, 5-е издание.-М.:«Диалектика», 2010.-656 c.

Рецензент: д-р техн. наук, доц. О. В. Шульга, Полтавський національний технічний університет ім. Юрія Кондратюка, Полтава Received (Надійшла) 11.06.2018 Accepted for publication (Прийнята до друку) 22.08.2018

\section{Розробка програмного сервісу з продажу автомобілів}

\section{Н. В. Ічанська, А. В. Гриценко, В. О. Шефер}

У статті вивчено програмне забезпечення з продажу автомобілів, його розробка та тестування, побудовано модель створення та розвитку сайту з продажу автомобілів на прикладі сайту з продажу автомобілів японських виробників. Оскільки сьогодні, все більшої популярності набирають інформаційні сайти окремих організацій або підрозділів, то можна визначити проблеми, які вирішує сервіс з продажу автомобілів. Робота заключається в тому, що саме активним користувачам мережі Інтернет приходять на допомогу Інтернет-магазини, або ж до прикладу сайти-сервіси 3 продажу автомобілів, призначені для перегляду відповідних комплектацій та характеристик автомобілів, не виходячи із власної оселі. На відміну від звичайного магазину, Інтернет-ресурс відкрито 24 години на добу, 7 днів на тиждень, доступний будь-якому користувачеві, в будь-якій точці планети і не потребує фінансових затрат на аренду приміщення, значно знижує витрати на персонал. Популярність Інтернет-сервісів зростає 3 кожним днем. Уже ні для кого не секрет, що добре «розкрученний» Інтернет-ресурс приносить доходів не менше, чим його звичайний аналог, причому утримувати $\mathrm{i}$ виготовляти Інтернет-ресурс на порядок вигідніше - відсутні затрати на дорогу, оренду і інші витрати Предметом дослідження роботи $\epsilon$ засоби реалізації Web-ресурсів. Основними завданням є реалізація засобів розробки структури Web-сайту та інтерфейсу, вибір засобів для їх реалізації, програмну реалізацію web-cайту. Мета роботи - покращення якості візуалізації інформації із автомобільної тематики програмного забезпечення шляхом створення сучасного вебсайту. Результати - запропоновано стратегію розвитку сайту та подальший його розвиток, що дозволяє забезпечити конкуруючі можливості створеного сайту. Описано методику створення програмного забезпечення та акцентовано на параметрах зручного використання сайту користувачем, висвітлено основні проблеми та недоліки існуючих сайтів та їх запровадження у порівнянні з новоствореним. Висновок - принципи розробки програмних сервісів, запропоновані у роботі, дозволяють забезпечити конкуруючі можливості інтернет-магазину, порівняно із аналогами. Розглянуті методи реалізують основні задачі проектування інформаційного наповнення сайту.

Ключові слова: програмне забезпечення, розробка сервісу, тестування сервісу, «юзабіліті», програмні засоби, інтернет-магазин, система керування вмістом, HTML5, CSS3, структура сайту.

\section{Разработка программного сервиса по продаже автомобилей}

\section{Н. В. Ичанская, А. В. Гриценко, В. А. Шефер}

В статье изучено программное обеспечение по продаже автомобилей, его разработка и тестирование, построена модель создания и развития сайта по продаже автомобилей на примере сайта по продаже автомобилей японских производителей. Поскольку сегодня, все большую популярность набирают информационные сайты отдельных организаций или подразделений, то можно определить проблемы, которые решает сервис по продаже автомобилей. Работа заключается в том, что именно активным пользователям сети Интернет приходят на помощь Интернет-магазины, или к примеру сайты-сервисы по продаже автомобилей, предназначенные для просмотра соответствующих комплектаций и характеристик автомобилей, не выходя из собственного дома. В отличие от обычного магазина, Интернет-ресурс открыт 24 часа в сутки, 7 дней в неделю, доступен любому пользователю, в любой точке планеты и не требует финансовых затрат на аренду помещения, значительно снижает расходы на персонал. Популярность интернетсервисов растет с каждым днем. Уже ни для кого не секрет, что хорошо «раскрутки» Интернет-ресурс приносит доходов не менее, чем его обычный аналог, причем удерживать и производить Интернет-ресурс на порядок вигиднишеотсутствуют затраты на дорогу аренду и другие расходы Предметом исследования работы являются средства реализации Web-peсурсов. Основными задачами являются реализация средств разработки структуры Web-сайта и интерфейса, выбор средств для их реализации, программную реализацию web-сайта. Цель работы - улучшение качества визуализации информации с автомобильной тематики программного обеспечения путем создания современного сайта. Результаты - предложено стратегию развития сайта и дальнейшее его развитие, что позволяет обеспечить конкурирующие возможности созданного сайта. Описаная методика создания программного обеспечения и акцентировано на параметрах удобного использования сайта пользователем, освещены основные проблемы и недостатки существующих сайтов и их внедрение в сравнении с вновь. Вывод - принципы разработки программных сервисов, предложенные в работе, позволяют обеспечить конкурирующие возможности интернет-магазина, по сравнению с аналогами. Рассмотрены методы реализуют основные задачи проектирования информационного наполнения сайта.

Ключевые слова: программные средства, интернет-магазин, система управления содержимым, WordPress, базы данных, язык гипертекстовой разметки, система управления базами данных, конкурентоспособность, методы разработки. 